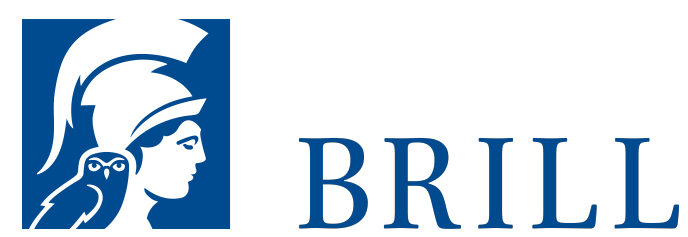

\title{
Isaiah and His Audience
}

The Structure and Meaning of Isaiah 1-12

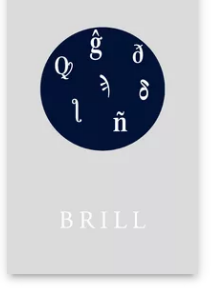

Author: Yehoshua Gitay

Pages: ix, 283

pp.

Language:

English

Subjects:

Literature,

Middle East and

Islamic Studies

Publisher: Brill

E-Book (PDF)

Released online:

o1 Jan 1991

ISBN: 978-90-

04-3586o-7 
For more information see brill.com

Order information: Order online at brill.com +44330 333 0049 | customerservices@brill.com Submission information: brill.com/authors

Titles published by Brill | Fink, Brill | mentis or Brill | Schöningh: +49(o)715413279216| brill@brocom.de 